\title{
Biochemical and Structural Characterization of Amy1: An Alpha-Amylase from Cryptococcus flavus Expressed in Saccharomyces cerevisiae
}

\author{
Alexsandro Sobreira Galdino, ${ }^{1}$ Roberto Nascimento Silva, ${ }^{2}$ \\ Muriele Taborda Lottermann, ${ }^{3}$ Alice Cunha Morales Álvares, ${ }^{3}$ \\ Lídia Maria Pepe de Moraes, ${ }^{4}$ Fernando Araripe Gonçalves Torres, ${ }^{4}$ \\ Sonia Maria de Freitas, ${ }^{3}$ and Cirano José Ulhoa ${ }^{5}$ \\ ${ }^{1}$ Laboratório de Biotecnologia, Universidade Federal de São João del-Rei, 35501-296 Divinópolis, MG, Brazil \\ ${ }^{2}$ Departamento de Bioquímica e Imunologia, Escola de Medicina, Universidade de São Paulo, 14049-900 Ribeirão Preto, SP, Brazil \\ ${ }^{3}$ Laboratório de Biofísica, Instituto de Biologia, Universidade de Brasília, 70910-900 Brasília, DF, Brazil \\ ${ }^{4}$ Laboratório de Biologia Molecular, Instituto de Biologia, Universidade de Brasília, 70910-900 Brasília, DF, Brazil \\ ${ }^{5}$ Laboratório de Enzimologia, Departamento de Ciências Fisiológicas (ICB), Universidade Federal de Goiás, \\ 74001-970 Goiânia, GO, Brazil \\ Correspondence should be addressed to Cirano José Ulhoa, ulhoa@icb.ufg.br
}

Received 31 October 2010; Accepted 18 December 2010

Academic Editor: Alane Beatriz Vermelho

Copyright (C) 2011 Alexsandro Sobreira Galdino et al. This is an open access article distributed under the Creative Commons Attribution License, which permits unrestricted use, distribution, and reproduction in any medium, provided the original work is properly cited.

\begin{abstract}
An extracellular alpha-amylase (Amy1) whose gene from Cryptococcus flavus was previously expressed in Saccharomyces cerevisiae was purified to homogeneity $(67 \mathrm{kDa})$ by ion-exchange and molecular exclusion chromatography. The enzyme was activated by $\mathrm{NH}_{4}{ }^{+}$and inhibited by $\mathrm{Cu}^{+2}$ and $\mathrm{Hg}^{+2}$. Significant biochemical and structural discrepancies between wild-type and recombinant $\alpha-$ amylase with respect to $\mathrm{K}_{m}$ values, enzyme specificity, and secondary structure content were found. Far-UV CD spectra analysis at $\mathrm{pH} 7.0$ revealed the high thermal stability of both proteins and the difference in folding pattern of Amyl compared with wild-type amylase from $C$. flavus, which reflected in decrease (10-fold) of enzymatic activity of recombinant protein. Despite the differences, the highest activity of Amyl towards soluble starch, amylopectin, and amylase, in contrast with the lowest activity of Amy $1_{\mathrm{w}}$, points to this protein as being of paramount biotechnological importance with many applications ranging from food industry to the production of biofuels.
\end{abstract}

\section{Introduction}

Starch is a major storage product of many economically important crops such as wheat, rice, cassava, and potato [1]. A large variety of microorganisms employ extracellular or intracellular enzymes to hydrolyze starch thus enabling its utilization as a source of energy. One of the most important groups of enzymes that process starch is represented by the $\alpha$-amylase family or family 13 glycosyl hydrolases [2, 3]. Amylases (EC 3.2.1.1, $\alpha-1,4-$ glucan-glucanohydrolase) are enzymes that hydrolyze starch polymers yielding diverse products including dextrins and smaller polymers of glucose. These enzymes are of great biotechnological interest with many applications ranging from food industry to the production of biofuels. Since each different application requires amylases with unique properties it is often necessary to search the biodiversity for new sources of these enzymes [4]. Several amylases isolated from yeasts such as Candida antarctica, Candida japonica [4], Lipomyces kononenkoae, Saccharomycopsis fibuligera, Schwanniomyces alluvius [5], Trichosporon pullulans, and Filobasidium capsuligenum [6] have been described. We have previously reported the characterization of an $\alpha$-amylase (Amyl) from the basidiomycetous yeast Cryptococcus flavus 
which exhibited important biochemical properties for its industrial utilization such as high stability at $\mathrm{pH} 5.5$ and optimal temperature at $50^{\circ} \mathrm{C}$ [7]. The gene encoding this $\alpha$ amylase (AMY1) was cloned and successfully expressed in Saccharomyces cerevisiae [8]. In order to assess the use of $S$. cerevisiae as a host for the heterologous production of Amy1 we sought the purification and enzymatic characterization of recombinant enzyme produced in this system.

\section{Material and Methods}

2.1. Strains. S. cerevisiae CENPK2 (MATa/ $\alpha$ ura3-52/ura3-52 leu 2-3,112 trp1-289/trp1-289 his3-1/his3-1).

2.2. Enzyme Purification. A colony of $S$. cerevisiae CENPK2 harboring YEpAMY was cultured in SD medium $(0,62 \%$ YNB, 2\% glucose, uracil, tryptophan, and histidine), and $2 \mathrm{~mL}$ of this preculture was transferred to $1 \mathrm{~L}$ conical flask containing $200 \mathrm{~mL}$ of the same medium following incubation at $28^{\circ} \mathrm{C}$ for $60 \mathrm{~h}(200 \mathrm{rpm})$. S. cerevisiae cells were harvested by centrifugation $(5,000 \mathrm{~g} / 10 \mathrm{~min})$, and the supernatant was dialyzed overnight against water and loaded on a Q-Sepharose fast flow column $(0.9 \times 18 \mathrm{~cm})$ previously equilibrated in $50 \mathrm{mM}$ sodium acetate ( $\mathrm{pH}$ 5.5). The column was washed with the same buffer, and proteins were eluted by a linear gradient of $0-0.5 \mathrm{M} \mathrm{NaCl}$. Four fractions of $3 \mathrm{~mL}$ were collected and monitored for the presence of proteins and amylase activity. These samples were collected, dialyzed, lyophilized, and resuspended in $1 \mathrm{~mL}$ of water and loaded on a Sephacryl S-200 HR $(2.5 \times 85 \mathrm{~cm})$ column previously equilibrated with $50 \mathrm{mM}$ sodium acetate containing $0.1 \mathrm{M}$ $\mathrm{NaCl}$. The column was washed with the same buffer at a flow rate of $12 \mathrm{~mL} \cdot \mathrm{h}^{-1}$. Fractions containing amylase activity were pooled, dialyzed against water, lyophilized, and stored at $-20^{\circ} \mathrm{C}$. In chromatography experiments, the protein content of each fraction was routinely monitored by measuring the absorbance at $280 \mathrm{~nm}$. Protein concentration was measured using serum albumin as standard [9].

2.3. Electrophoresis and Zymogram Analysis. Protein integrity and the molecular mass calculation were performed by running samples on $12 \%$ sodium dodecyl sulfate-polyacrilymide gels [10]. Proteins were silver-stained as described by manufacturer [11] (1987). Molecular mass markers (Fermentas Life Sciences) were as follows: $\beta$-galactosidase $(116 \mathrm{kDa})$, bovine serum albumin $(66.2 \mathrm{kDa})$, ovalbumin $(45 \mathrm{kDa})$, lactate dehydrogenase $(35 \mathrm{kDa})$, REase Bsp98I $(25 \mathrm{kDa})$, $\beta$-lactoglobulin $(18.4 \mathrm{kDa})$, and lysozyme $(14.4 \mathrm{kDa})$ by manufacturer. Activity gels (zymogram) were performed after running samples on 12\% nondenaturing PAGE. Gels were washed with distilled water, incubated with $50 \mathrm{mM}$ sodium acetate ( $\mathrm{pH}$ 5.5) for $60 \mathrm{~min}$, and then incubated at $4^{\circ} \mathrm{C}$ for $12 \mathrm{~h}$ in a solution containing $0.5 \%$ of starch (in $50 \mathrm{mM}$ sodium acetate buffer [pH 5.5]). The gel was then incubated at $37^{\circ} \mathrm{C}$ for $2 \mathrm{~h}$, and bands with amylase activity were detected after staining with iodine solution $\left(1 \mathrm{mM} \mathrm{I}_{2}\right.$ in $0.5 \mathrm{M} \mathrm{KI})$.
2.4. Amylase Assay. $\alpha$-amylase dextrinizing activity was assayed in a reaction system containing $100 \mu \mathrm{L} 0.5 \%(\mathrm{w} / \mathrm{v})$ soluble starch, $40 \mu \mathrm{L} 0.5 \mathrm{M}$ acetate buffer (pH 5.5), enzyme solution $(0-60 \mu \mathrm{L})$, and water to a total volume of $200 \mu \mathrm{L}$. After $10 \mathrm{~min}$ at $60^{\circ} \mathrm{C}$, the reaction was stopped with $200 \mu \mathrm{L} \mathrm{1.0} \mathrm{M} \mathrm{acetic} \mathrm{acid.} \mathrm{Iodine} \mathrm{reagent} \mathrm{was} \mathrm{then} \mathrm{added} \mathrm{to}$ determine dextrinizing activity [12]. Saccharifying activity was determined by measuring the production of reducing sugars from starch by using the dinitrosalicylic acid (DNS) method [13]. One unit of dextrinizing activity was defined as the amount of enzyme necessary to hydrolyse $0.1 \mathrm{mg}$ starch/min. One unit of saccharifying activity was defined as the amount of enzyme necessary to produce $1 \mathrm{mg}$ glucose equivalent/min.

2.5. Enzyme Characterization. The optimum $\mathrm{pH}$ of the recombinant amylase was determined by varying the $\mathrm{pH}$ of the reaction mixtures using the following buffers $(50 \mathrm{mM})$ : glycine- $\mathrm{HCl}(\mathrm{pH} 1.0-3.0)$, sodium acetate $(\mathrm{pH} 4.0-5.5)$, sodium phosphate ( $\mathrm{pH}$ 6.0-7.0), and Tris- $\mathrm{HCl}(\mathrm{pH} 8.0-10)$ at $60^{\circ} \mathrm{C}$. In order to determine $\mathrm{pH}$ stability, the enzyme was preincubated in different buffers for $60 \mathrm{~min}$ at $60^{\circ} \mathrm{C}$. The residual enzyme activity was assayed in $50 \mathrm{mM}$ sodium acetate buffer ( $\mathrm{pH}$ 5.5). The optimum estimated temperature of the enzyme was evaluated by measuring amylase activity at different temperatures $\left(30^{\circ} \mathrm{C}\right.$ to $\left.70^{\circ} \mathrm{C}\right)$ in $50 \mathrm{mM}$ sodium acetate ( $\mathrm{pH}$ 5.5). The effect of temperature on enzyme stability was determined by measuring the residual activity after $15,30,45$, and $60 \mathrm{~min}$ of preincubation in $50 \mathrm{mM}$ sodium acetate $(\mathrm{pH} 5.5)$ at 55 and $60^{\circ} \mathrm{C}$. In order to determine the effect of metal ions, the assay was performed after preincubation of the enzyme with various metal ions at a final concentration of $4 \mathrm{mM}$. The effect of $10 \mathrm{mM}$ $\mathrm{CaCl}_{2}$ and DTT $(5-10 \mathrm{mM})$ was also evaluated. $K_{m}$ values for the purified enzyme were determined by incubating the enzyme with $0-0.8 \mathrm{mg} \cdot \mathrm{mL}^{-1}$ soluble starch in $50 \mathrm{mM}$ sodium acetate $(\mathrm{pH} 5.5)$ at $60^{\circ} \mathrm{C}$. The data obtained were fitted to a standard Lineweaver-Burk model using linear least squares regression.

2.6. Thin Layer Chromatography Analysis. Briefly, purified amylase was incubated with $0.5 \%$ starch, glycogen, pullulan, amylase, and amylopectin, in $50 \mathrm{mM}$ sodium acetate $(\mathrm{pH}$ $5.5)$ at $40^{\circ} \mathrm{C}$. Aliquots $(10 \mu \mathrm{L})$ were removed after incubation for 6 and $12 \mathrm{~h}$. The chromatogram was developed with $n$ butanol/methanol $/ \mathrm{H}_{2} \mathrm{O}(4: 2: 1)$. Sugars were detected by thin-layer chromatography [14].

2.7. Circular Dichroism Spectroscopy. Circular Dichroism (CD) assays were carried out using Jasco J-815 spectropolarimeter (Jasco, Tokyo, Japan) equipped with a Peltier type temperature cuvette holder. Far-UV spectra were recorded using $0.1 \mathrm{~cm}$ path length quartz cuvette. Proteins $(0.085$ to $0.100 \mathrm{mg} / \mathrm{mL}$ ) were analyzed in $2 \mathrm{mM}$ glycine $\mathrm{pH} 3.0$ and 4.0, $2 \mathrm{mM}$ sodium acetate $\mathrm{pH} 5.5,2 \mathrm{mM}$ Tris- $\mathrm{HCl} \mathrm{pH} 7.0$ and 8.0. We used CD data over the wavelength range 260 $200 \mathrm{~nm}$ to ensure a satisfactory CD signal and to prevent the high signal-noise ratio. Four consecutive measurements were 
TABLE 1: Summary of the purification steps of Amy1.

\begin{tabular}{lccccc}
\hline Step & Total activity $(\mathrm{U})$ & $\begin{array}{c}\text { Total protein } \\
\left(\mathrm{mg} \times 10^{-3}\right)\end{array}$ & $\begin{array}{c}\text { Specific activity } \\
\left(\mathrm{U} / \mathrm{mg} \times 10^{-3}\right)\end{array}$ & Purification (fold) & Yield (\%) \\
\hline Supernatant & 1922.2 & 1.750 & 1098.5 & 1.00 & 100.0 \\
Q-Sepharose & 490.8 & 0.120 & 4090.0 & 3.72 & 25.4 \\
Sephacryl S-200HR & 199.9 & 0.048 & 4164.5 & 3.79 & 10.3 \\
\hline
\end{tabular}

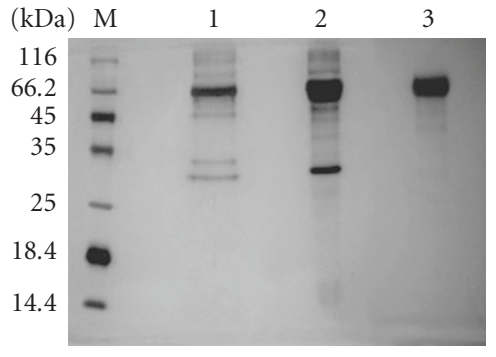

(a)

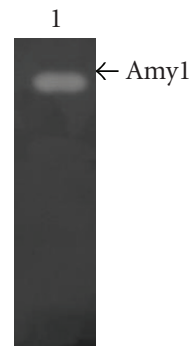

(b)
Figure 1: (a) Analysis of purified recombinant Amyl on 12\% SDS-PAGE; M, standard marker proteins; lane 1, lane 2, protein profile after ion exchange on Q-Sepharose column; lane 3, purified recombinant amylase after gel filtration on Sephacryl S-200HR column. (b) Detection of amylase activity on non-denaturing PAGE.

accumulated, and the mean spectra were corrected for the baseline contribution of the buffer. Thermal denaturation assays were performed raising the temperature from 25 to $95^{\circ} \mathrm{C}$. The observed ellipticities were converted into molar ellipticity $([\theta])$ based on molecular mass per residue of $115 \mathrm{Da}$. Protein structure and thermal unfolding curves were tracked by changes in $[\theta]$ at 222 or $206 \mathrm{~nm}$.

The temperature dependence of the secondary structure was estimated from the Far-UV CD curves adjustments using the CDNN deconvolution software (Version 2.1, Bioinformatik.biochemtech.uni-halle.de/cdnn) [15].

\section{Results and Discussion}

3.1. Purification of Amy1. Amyl was purified from the supernatant of $S$. cerevisiae cultures in a two-step chromatographic procedure. Elution profiles of both Q-Sepharose and Sephacryl-S200HR chromatography showed one peak with amylase activity (data not shown). This fraction was collected, dialyzed, and concentrated by lyophilization. The enzyme was purified to homogeneity with 3.79-fold increase in specific activity with a yield of $\sim 10.3 \%$ as compared to the supernatant (Table 1). Comparing with the recombinant enzyme, wild-type Amyl was purified from $C$. flavus cultures in only a single purification step [7]. SDSPAGE analysis of the purified recombinant amylase showed a single protein band corresponding to $\sim 67 \mathrm{kDa}$ (Figure 1 (a)) which showed $\alpha$-amylase activity after zymogram analyses (Figure 1(b)). Among the amylase-producing yeasts and filamentous fungi, the $\alpha$-amylases from Cryptococcus sp S-2 [16],
TABle 2: Effect of ions on purified Amyl.

\begin{tabular}{lc}
\hline Compound $(4 \mathrm{mM})$ & Relative activity $(\%)$ \\
\hline Control & 100 \\
$\mathrm{MgSO}_{4}$ & 88.6 \\
$\mathrm{MnSO}_{4}$ & 77.9 \\
$\mathrm{CaCl}_{2}$ & 71.6 \\
$\left(\mathrm{NH}_{4}\right)_{2} \mathrm{SO}_{4}$ & 111 \\
$\mathrm{ZnCl}_{2}$ & 20.1 \\
$\mathrm{CuSO}_{4}$ & 0 \\
$\mathrm{HgSO}_{4}$ & 0 \\
\hline
\end{tabular}

Aspergillus fumigatus [17], Lipomyces starkeyi [18], and Lipomyces kononenkoae [19] showed similar molecular masses as Amyl produced in S. cerevisiae.

3.2. Enzyme Characterization. The optimum $\mathrm{pH}$ for the recombinant enzyme was determined as $\mathrm{pH} 5.5$ (Figure 2(a)). Amyl was tested for $\mathrm{pH}$ stability by preincubating the purified enzyme in appropriate buffers for 1 hour. The data suggest that Amyl is tolerant to wide $\mathrm{pH}$ range (Figure $2(\mathrm{~b})$ ). This result was similar to that found for $\alpha$-amylases from a variety of yeast strains [20,21]. The optimum $\mathrm{pH}$ for yeast $\alpha$-amylase activity is usually in the range of 4.0 and $6.0[5,7,16,21]$.

Amylase activity measured as a function of temperature from 30 to $70^{\circ} \mathrm{C}$ shows that the activity was the highest at $60^{\circ} \mathrm{C}$ (Figure $2(\mathrm{c})$ ). This optimum temperature is in agreement with the $\alpha$-amylases from Cryptococcus sp S-2 treated with $1 \mathrm{mM} \mathrm{CaCl}_{2}$ [16] and Aureobasidium pullulans N13d [20]. Thermostability is considered an important and useful criterion for industrial application of $\alpha$-amylase from microorganisms. As shown in Figure 2(d), the residual amylase activity is practically constant at $55^{\circ} \mathrm{C}$ after $1 \mathrm{~h}$ of incubation. However, at $60^{\circ} \mathrm{C} 50 \%$ of the residual activity was lost. Iefuji et al. [16] proposed that the C-terminal raw starch binding motifs present in Cryptococcus sp S-2 amylase (AMY-CS2) might be related to the thermostability presented by this amylase. Because Amy1 has 97\% sequence identity with AMY-CS2 [8] it is possible that the same explanation applies to Amyl.

The results presented on Table 2 indicate that recombinant Amyl is poorly affected by most of the $4 \mathrm{mM}$ ions tested $\mathrm{Mg}^{2+}, \mathrm{Mn}^{2+}$, and $\left.\mathrm{Ca}^{2+}\right)$ since the relative activity was higher than $70 \%$. In addition, it was also found that in the presence of $10 \mathrm{mM} \mathrm{CaCl}$, Amyl still maintained its original activity (data not shown) which shows that 


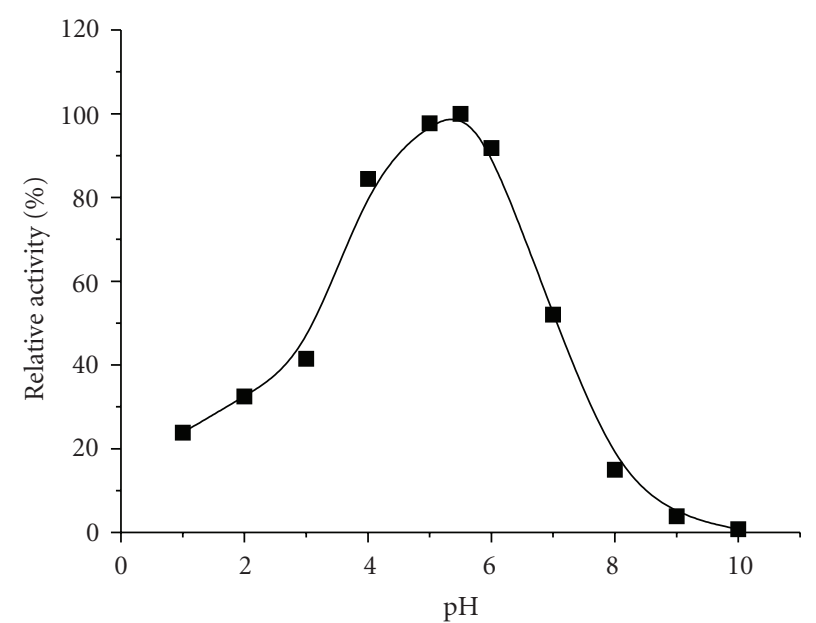

(a)

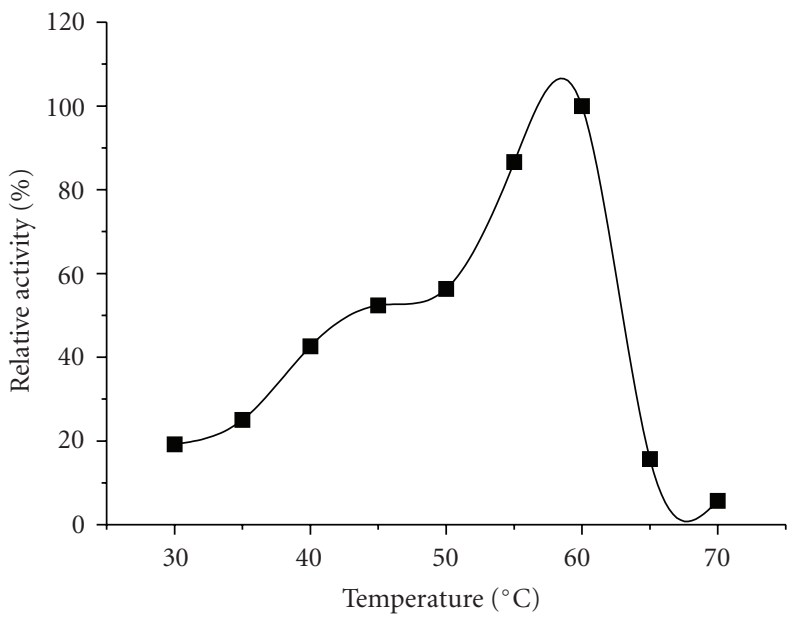

(c)

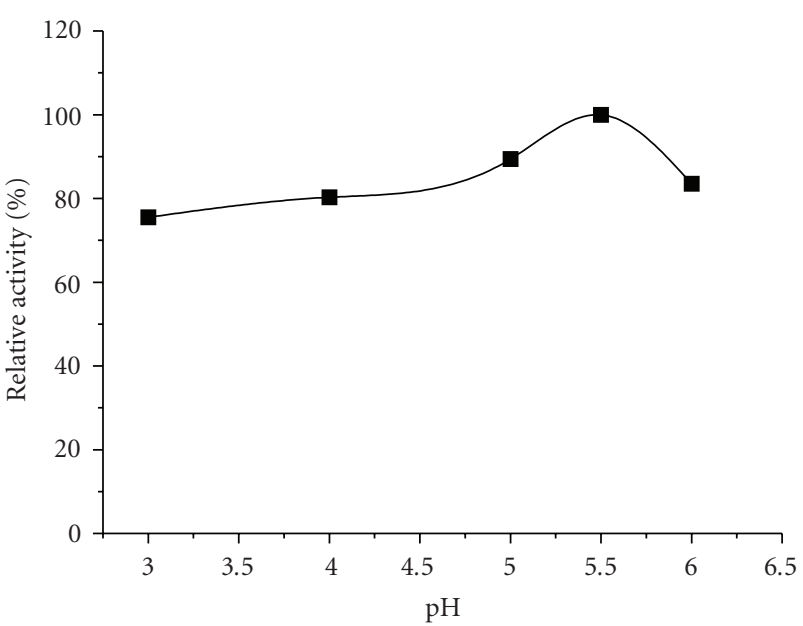

(b)

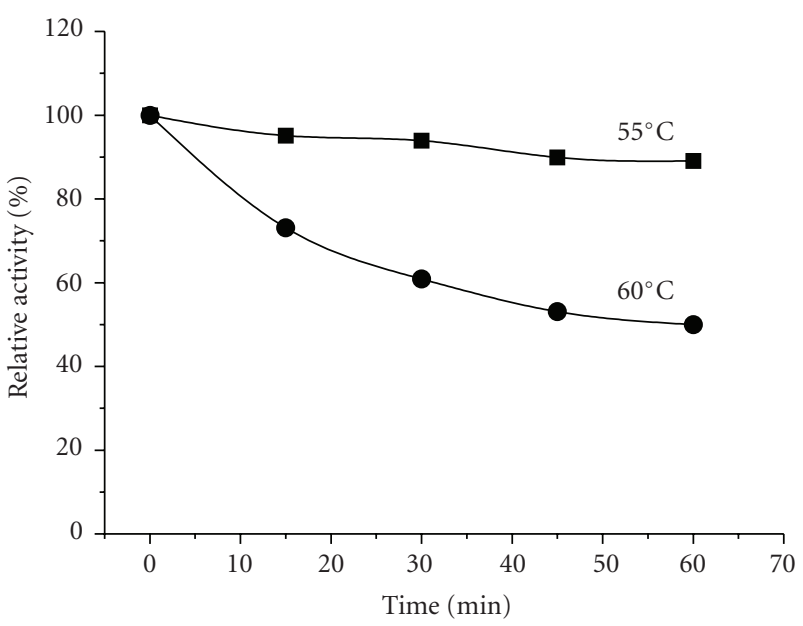

(d)

FIGURE 2: Effect of $\mathrm{pH}(\mathrm{a}-\mathrm{b})$ and temperature (c-d) on Amyl activity and stability, respectively. The $\mathrm{pH}$ optimum and pH stability were determined by varying the $\mathrm{pH}$ of the reaction mixtures and preincubating the enzyme in different buffers for $60 \mathrm{~min}$ at $55^{\circ} \mathrm{C}(\mathrm{square})$ and $60^{\circ} \mathrm{C}$ (circle). The temperature optimum was evaluated by measuring amylase activity at different temperatures, and the effect of temperature on enzyme stability was determined by measuring the residual activity after 15, 30, 45, and 60 min of preincubation in 50 mM sodium acetate $(\mathrm{pH} 5.5)$ at 55 and $60^{\circ} \mathrm{C}$.

this enzyme is not affected by $\mathrm{Ca}^{+2}$. Similar behavior was found for wild-type Amy1. However, Takeuchi et al. [22] related that the Pichia burtonii $\alpha$-amylase was activated by $\mathrm{Ca}^{+2}(135 \%)$. These authors proposed that the activation of enzyme by calcium ions probably happened during the purification procedure when the enzyme lost activity. The Bacillus halodurans 38C-21 $\alpha$-amylase also had its activity increased in presence of $\mathrm{Ca}^{2+}$ [23]. The presence of $\mathrm{NH}_{4}^{+}$ ions had the most prominent activating effect $(111 \%)$ on recombinant Amyl. However, $\mathrm{Zn}^{2+}, \mathrm{Cu}^{2+}$, and $\mathrm{Hg}^{2+}$ acted as inhibitors of amylase activity, with $\mathrm{Cu}^{+2}$ and $\mathrm{Hg}^{2+}$ showing a complete inhibition (Table 2). The inhibition by $\mathrm{Hg}^{2+}$ may indicate the importance of indole group of amino acid residues in enzyme function $[4,24]$. The wild-type amylase is inhibited by $\mathrm{Hg}^{2+}, \mathrm{Ag}^{+}, \mathrm{Cu}^{2+}$, and $\mathrm{Mg}^{2+}$ [16] while that from L. kononenkoae CBS 5608 is inhibited by $\mathrm{Ag}^{+}$and $\mathrm{Cu}^{2+}$ [21]. Interestingly, the amylase from yeast Aureobasidium pullulans
N13d is not inhibited by $\mathrm{Cu}^{2+}$ which had an activating effect on the purified enzyme [20]. DTT is frequently used to reduce and prevent intramolecular and intermolecular disulfide bonds. The enzyme's activity was practically constant when DTT (4-25 mM) was used (data not shown). This result was different from that observed with the Thermotoga maritima MSB8 amylase expressed in E. coli which showed increased activity in presence of DDT ranging from 5 to $10 \mathrm{mM}[25]$.

Wanderley et al. [7] reported that the $K_{m}$ for wildtype Amyl was $0.056 \mathrm{mg} \cdot \mathrm{mL}^{-1}$ which is considerably smaller than the $K_{m}$ observed for the recombinant amylase $\left(0.37 \mathrm{mg} \mathrm{mL}^{-1}\right)$ which showed Michaelis-Menten type kinetics with soluble starch as substrate. The $K_{m}$ of the recombinant enzyme is similar to other yeast amylases such as Schwanniomyces alluvius [5] and Thermomonospora curvata [26]. 
In order to establish the specificity of recombinant Amyl, the enzyme was incubated with starch, amylopectin, amylose, glycogen, and pullulan. These substrates consist of different glucose polymers containing $\alpha-1,4$ linkages or a mixture of $\alpha-1,4-$ and $\alpha-1,6$-glucosidic linkages. Amy1 showed the highest activity towards soluble starch (100\%) amylopectin $(97.9 \%)$, amylose $(50.6 \%)$ but no activity was observed on pullulan. This result is similar to that observed for the Bacillus subtilis truncated $\alpha$-amylase produced in E. coli [27], but different from that observed for wildtype Amyl which showed the highest activity towards starch (100\%), glycogen (18.9\%), amylopectin (16.7\%), and amylose $(7.1 \%)$. The recombinant enzyme displayed typical $\alpha$-amylase properties based on the evidence that oligosaccharides from several sizes were the main products from the digestion of glycogen, amylose, amylopectin, and starch (Figure 3).

3.3. Conformational Stability of Amy. Structural characterization of recombinant (Amyl) and wild-type $\left(A m y_{w}\right)$ amylase from C. flavus was carried out by circular dichroism spectroscopy for comparison. Far-UV CD spectra of Amy1 and $A m y 1_{\mathrm{w}}$ at $\mathrm{pH} 7.0$ and $25^{\circ} \mathrm{C}$ are quite different showing typical features of beta/unordered and beta/ $\alpha$-helix secondary structure pattern, respectively (Figure $4(\mathrm{a})$ ). While the $222 \mathrm{~nm}$ dichroic band is predominantly associated with $\alpha$-helical structure, the dichroic band at 198 and $206 \mathrm{~nm}$ may arise from changes in other secondary structure elements in the protein, as unordered or beta structure. The secondary structure content of both proteins slightly differs on helical (Amy1, 5.7\% and $A m y 1_{w}, 9.5 \%$ ) and antiparallel $\beta$-sheet (Amyl, $42.1 \%$ and $A m y 1_{w}, 32.4 \%$ ) and is similar for other secondary structures.

Thermal stability of the proteins at $\mathrm{pH} 7.0$ was assessed upon raising the temperature from 20 to $95^{\circ} \mathrm{C}$ (Figures 4 (b) and $4(\mathrm{~d})$ ). The thermal denaturation curves analyzed from Far-UV CD measurements at 206 and $222 \mathrm{~nm}$ at pH 7.0 strongly indicated the Amy $1_{\mathrm{w}}$ and Amy1 as thermally stable proteins since no pattern of protein denaturation could be verified (data not shown). Indeed, although the CD spectra of the $A m y 1_{w}$ in this condition show a gradual increase (downward) of the dichroic bands at $206 \mathrm{~nm}$ and slight at $222 \mathrm{~nm}$ (Figure 4(d)), no secondary structure changes were detected suggesting only conformational changes of protein or secondary structure rearrangement as a function of temperature. In contrast, CD spectra of the Amy1 show a gradual increase and decrease of the dichroic bands at 222 and $200 \mathrm{~nm}$, respectively, suggesting the alteration of helical and $\beta$-sheet structures content (Figure 4(b)). A slight increase was observed in terms of $\alpha$-helix (from $5.7 \%$ to $6.8 \%$ ) and decrease of $\beta$-sheet (from $42.1 \%$ to $38.8 \%$ ) when raising the temperature from 25 to $95^{\circ} \mathrm{C}$. Altogether, these results revealed the high thermal stability of both proteins and the difference in folding pattern of Amyl compared with wild-type amylase from $C$. flavus reflecting in decrease (10-fold) of enzymatic activity ( $K_{m}$ values) of recombinant protein using a soluble starch as substrate, as discussed above.

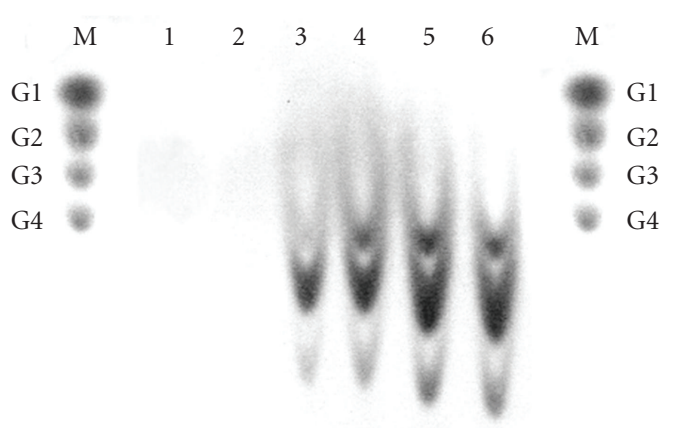

FIGURE 3: Thin-layer chromatogram of products released from starch after treatment with recombinant Amyl. The standards used were glucose (G1), maltose (G2), maltotriose (G3), and maltotetraose (G4). Lane 1, control (starch without enzyme); lane 2 , pullulan; lane 3 , glycogen; lane 4 , amylose; lane 5 , amylopectin, and lane 6 , soluble starch.

Besides significant distinction in $\mathrm{pH}$ region where the maximum enzymatic activity of Amyl occurred (Figure 2(a)), the protein achieved similar secondary structure content (helical $5.7 \%-6.5 \%$ and $\beta$-sheet $\sim 42 \%$ ) in a broad range of $\mathrm{pH}(\mathrm{pH} 3.0,5.5$, and 7.0), as indicated by the $\mathrm{CD}$ spectra (Figure 4(c)) and CDNN estimative. At pH 8.0 as well as $\mathrm{pH} 4.0$, it was verified the mainly increase in the CD signal at $200 \mathrm{~nm}$ (Figure 4(c)), compatible with minor $\beta$-sheet structures content $(\sim 37 \%)$ compared with $\mathrm{pH} 3.0$, 5.5 , and $7.0(\sim 42 \%)$. Noteworthy, although no secondary structure changes have been observed, analogous or different conformation of Amyl side chains could occur as a function of those $\mathrm{pHs}$, as judged by the relative activity of the enzyme in these condition (Figures 2(a) and 2(b)). In these cases, some important structural changes related with side chains ionization of aspartate, glutamate, and histidine residues at $\mathrm{pH} 4.0$ and 5.5 could occur and are fundamental to enzyme activity.

In this work we have observed some significant biochemical and slight structural discrepancies between wild-type and recombinant Amyl especially with respect to $K_{m}$ values, enzyme specificity, and helical and $\beta$-sheet structure content. These could be explained by small folding alterations in the structure of recombinant amylase during its expression. Different patterns of protein glycosylation between $C$. flavus and $S$. cerevisiae could also account for these differences. In fact, three putative $N$-glycosylation sites have been identified in Amyl [8]. Work is under way to assess the role of glycosylation on the activity of Amyl. Because recombinant Amy1 showed considerable thermostability, its use in biotechnological processes should be considered.

\section{Conclusion}

In conclusion, the enzymatic and structural features of Amyl, the highest activity towards soluble starch, amylopectin, and amylase, in contrast with the lowest activity of $A m y 1_{W}$, points out this protein as being of paramount 


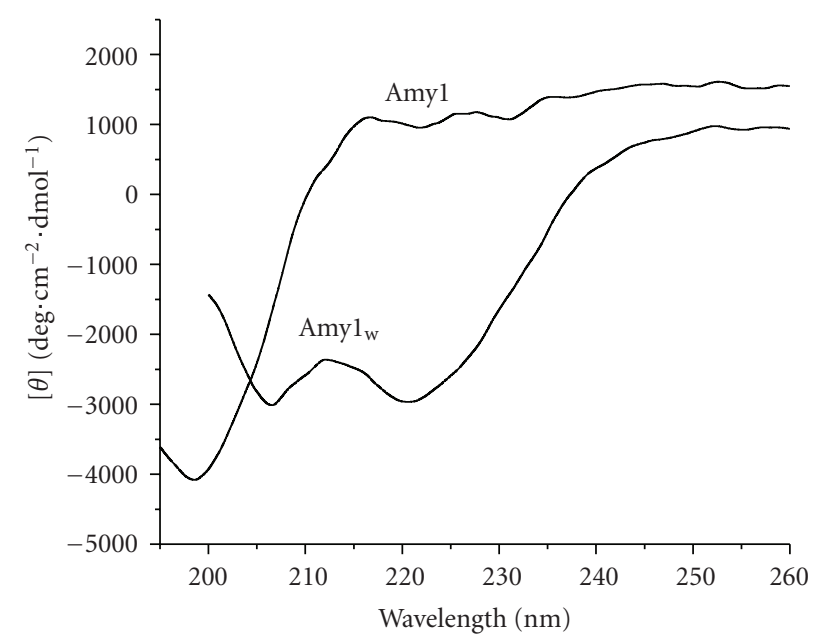

(a)

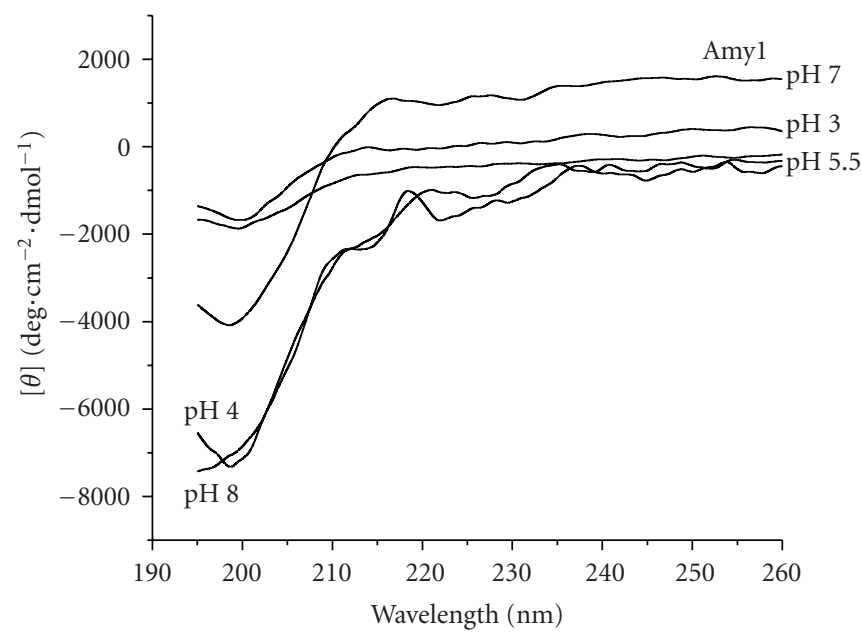

(c)

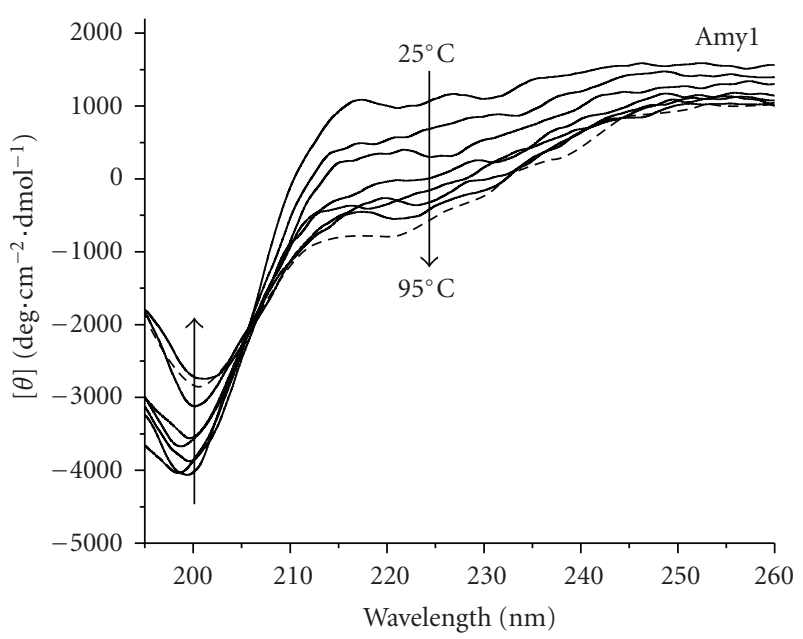

(b)

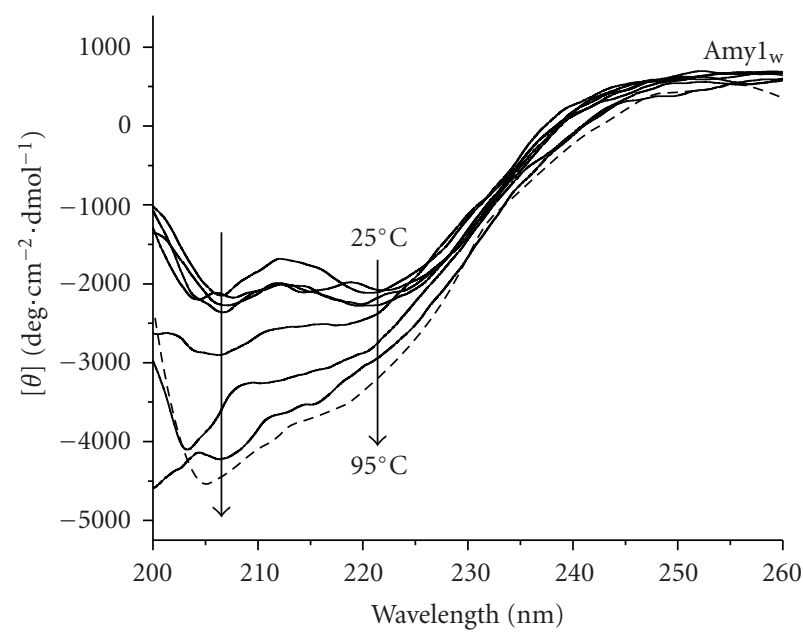

(d)

Figure 4: Far-UV circular dichroism analyses. Residual molar ellipticity [ $\theta$ ] was measured from 200 to $260 \mathrm{~nm}$ at $25^{\circ} \mathrm{C}$ or temperature arising from 25 to $95^{\circ} \mathrm{C}$. (a) The distinct spectra of wild-type $\left(A m y 1_{w}\right)$ and recombinant $(A m y 1)$ amylase are shown, indicating that they had different amount of secondary structure (see Section 3). (b) Effect of temperature on secondary structure of Amy1. Changes in molar ellipticity at 222 and $200 \mathrm{~nm}$ are shown as a function of temperature. (c) Effect of $\mathrm{pH}$ on secondary structure of Amyl. Note the slight differences of CD spectra at $\mathrm{pH}$ 7.0, 3.0, and 5.5 and similarity of CD spectra at $\mathrm{pH} 4.0$ and 8.0. (d) Effect of temperature on secondary structure of $A m y 1_{\mathrm{w}}$. Changes in molar ellipticity at 222 and $206 \mathrm{~nm}$ are shown as a function of temperature.

biotechnological importance with many applications ranging from food industry to the production of biofuels.

\section{Acronyms}

SD: $\quad$ Synthetic dextrose minimal media

YNB: Yeast nitrogen base

REase: Ribonuclease

PAGE: Polyacrilymide gel electrophoresis

DTT: Dithiothreitol

CDNN: Neural network circular dichroism.

\section{Acknowledgments}

This work was supported by a biotechnology research grant to C. J. Ulhoa and F. A. G. Torres (CNPq, FINEP, and
FUNAPE/UFG). A. S. Galdino was supported by CAPES/ Brazil.

\section{References}

[1] M. J. E. C. Van Der Maarel, B. Van Der Veen, J. C. M. Uitdehaag, H. Leemhuis, and L. Dijkhuizen, "Properties and applications of starch-converting enzymes of the $\alpha$-amylase family," Journal of Biotechnology, vol. 94, no. 2, pp. 137-155, 2002.

[2] B. Henrissat, "A classification of glycosyl hydrolases based on amino acid sequence similarities," Biochemical Journal, vol. 280, no. 2, pp. 309-316, 1991.

[3] B. Henrissat and A. Bairoch, "Updating the sequence-based classification of glycosyl hydrolases," Biochemical Journal, vol. 316, no. 2, pp. 695-696, 1996.

[4] R. Gupta, P. Gigras, H. Mohapatra, V. K. Goswami, and B. Chauhan, "Microbial $\alpha$-amylases: a biotechnological 
perspective," Process Biochemistry, vol. 38, no. 11, pp. 15991616, 2003.

[5] J. J. Wilson and W. M. Ingledew, "Isolation and characterization of Schwanniomyces alluvius amylolytic enzymes," Applied and Environmental Microbiology, vol. 44, no. 2, pp. 301-307, 1982.

[6] R. De Mot and H. Verachtert, "Secretion of $\alpha$-amylase and multiple forms of glucoamylase by the yeast Trichosporon pullulans," Canadian Journal of Microbiology, vol. 32, no. 1, pp. 47-51, 1986.

[7] K. J. Wanderley, F. A. G. Torres, L. M. P. Moraes, and C. J. Ulhoa, "Biochemical characterization of $\alpha$-amylase from the yeast Cryptococcus flavus," FEMS Microbiology Letters, vol. 231, no. 2, pp. 165-169, 2004.

[8] A. S. Galdino, C. J. Ulhoa, L. M. P. Moraes, M. V. Prates, C. Bloch, and F. A. G. Torres, "Cloning, molecular characterization and heterologous expression of AMY1, an $\alpha$-amylase gene from Cryptococcus flavus," FEMS Microbiology Letters, vol. 280, no. 2, pp. 189-194, 2008.

[9] M. M. Bradford, "A rapid and sensitive method for the quantitation of microgram quantities of protein utilizing the principle of protein dye binding," Analytical Biochemistry, vol. 72, no. 1-2, pp. 248-254, 1976.

[10] U. K. Laemmli, "Cleavage of structural proteins during the assembly of the head of bacteriophage T4," Nature, vol. 227, no. 5259, pp. 680-685, 1970.

[11] H. Blum, H. Bier, and H. Gross, "Improved silver staining of plants proteins, RNA and DNA in polyacrylamide gels," Electrophoresis, vol. 8, pp. 93-99, 1987.

[12] H. Fuwa, "A new method for microdetermination of amylase activity by the use of amylose as the substrate," Journal of Biochemistry, vol. 41, no. 5, pp. 583-603, 1954.

[13] G. L. Miller, "Use of dinitrosalicylic acid reagent for determination of reducing sugar," Analytical Chemistry, vol. 31, no. 3, pp. 426-428, 1959.

[14] M. Lato, B. Brunelli, G. Ciuffini, and T. Mezzetti, "Thin-layer chromatography of carbohydrates on silica gel impregnated with sodium acetate, monosodium phosphate and disodium phosphate," Journal of Chromatography A, vol. 39, pp. 407417, 1969.

[15] G. Bohm, R. Muhr, and R. Jaenicke, "Quantitative analysis of protein far UV circular dichroism spectra by neural networks," Protein Engineering, vol. 5, no. 3, pp. 191-195, 1992.

[16] H. Iefuji, M. Chino, M. Kato, and Y. Iimura, "Raw-starchdigesting and thermostable $\alpha$-amylase from the yeast Cryptococcus sp. S-2: purification, characterization, cloning and sequencing," Biochemical Journal, vol. 318, no. 3, pp. 989-996, 1996.

[17] C. E. Goto, E. P. Barbosa, L. C. L. Kistner, F. G. Moreira, V. Lenartovicz, and R. M. Peralta, "Production of amylase by Aspergillus fumigatus utilizing $\alpha$-methyl-D-glycoside, a synthetic analogue of maltose, as substrate," FEMS Microbiology Letters, vol. 167, no. 2, pp. 139-143, 1998.

[18] H. K. Kang, J. H. Lee, D. Kim et al., "Cloning and expression of Lipomyces starkeyi $\alpha$-amylase in Escherichia coli and determination of some of its properties," FEMS Microbiology Letters, vol. 233, no. 1, pp. 53-64, 2004.

[19] A. J. C. Steyn, J. Marmur, and I. S. Pretorius, "Cloning, mapping and characterization of a genomic copy of the Lipomyces kononenkoae $\alpha$-amylase-encoding gene (LKA1)," Yeast, vol. 12, no. 10, pp. 925-937, 1996.

[20] H. Li, Z. Chi, X. Wang, X. Duan, L. Ma, and L. Gao, "Purification and characterization of extracellular amylase from the marine yeast Aureobasidium pullulans N13d and its raw potato starch digestion," Enzyme and Microbial Technology, vol. 40, no. 5, pp. 1006-1012, 2007.

[21] J. A. Prieto, B. R. Bort, J. Martínez, F. Randez-Gil, C. Buesa, and P. Sanz, "Purification and characterization of a new alpha-amylase of intermediate thermal stability from the yeast Lipomyces kononenkoae," Biochemistry and Cell Biology, vol. 73, no. 1-2, pp. 41-49, 1995.

[22] A. Takeuchi, A. Shimizu-Ibuka, Y. Nishiyama et al., "Purification and characterization of an $\alpha$-amylase of Pichia burtonii isolated from the traditional starter "murcha" in Nepal," Bioscience, Biotechnology and Biochemistry, vol. 70, no. 12, pp. 3019-3024, 2006.

[23] S. Murakami, H. Nishimoto, Y. Toyama et al., "Purification and characterization of two alkaline, thermotolerant $\alpha$ amylases from Bacillus halodurans 38C-2-1 and expression of the cloned gene in Escherichia coli," Bioscience, Biotechnology and Biochemistry, vol. 71, no. 10, pp. 2393-2401, 2007.

[24] F. Moranelli, M. Yaguchi, G. B. Calleja, and A. Nasim, "Purification and characterization of the extracellular alpha-amylase activity of the yeast Schwanniomyces alluvius," Biochemistry and Cell Biology, vol. 65, no. 10, pp. 899-908, 1987.

[25] M. Ballschmiter, O. Fütterer, and W. Liebl, "Identification and characterization of a novel intracellular alkaline $\alpha$-amylase from the hyperthermophilic bacterium Thermotoga maritima MSB8," Applied and Environmental Microbiology, vol. 72, no. 3, pp. 2206-2211, 2006.

[26] J. L. Glymph and F. J. Stutzenberger, "Production, purification, and characterization of $\alpha$-amylase from Thermomonospora curvata," Applied and Environmental Microbiology, vol. 34, no. 4, pp. 391-397, 1977.

[27] J. L. Marco, L. A. Bataus, F. F. Valencia, C. J. Ulhoa, S. AstolfiFilho, and C. R. Felix, "Purification and characterization of a truncated Bacillus subtilis $\alpha$-amylase produced by Escherichia coli," Applied Microbiology and Biotechnology, vol. 44, no. 6, pp. 746-752, 1996. 

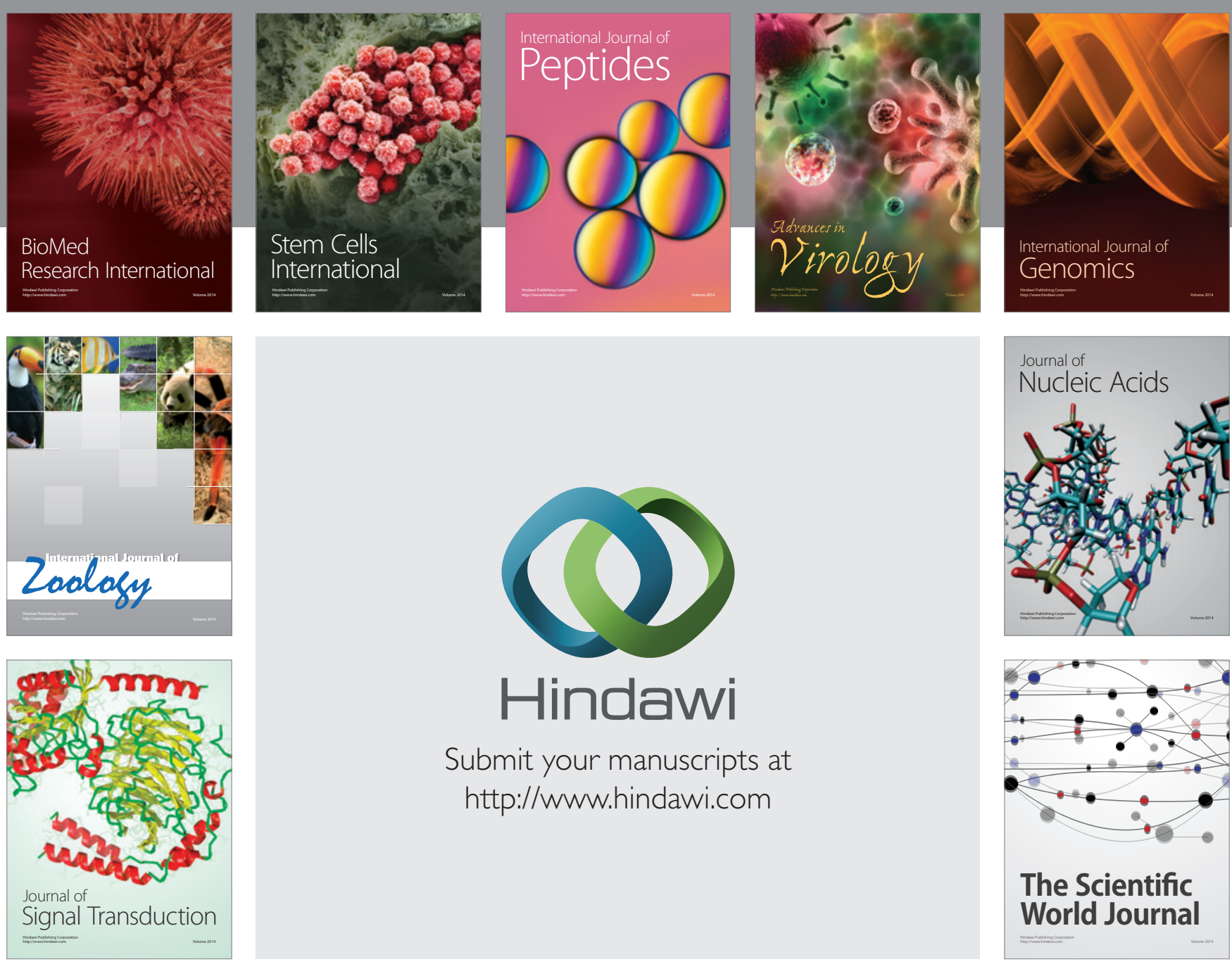

Submit your manuscripts at

http://www.hindawi.com
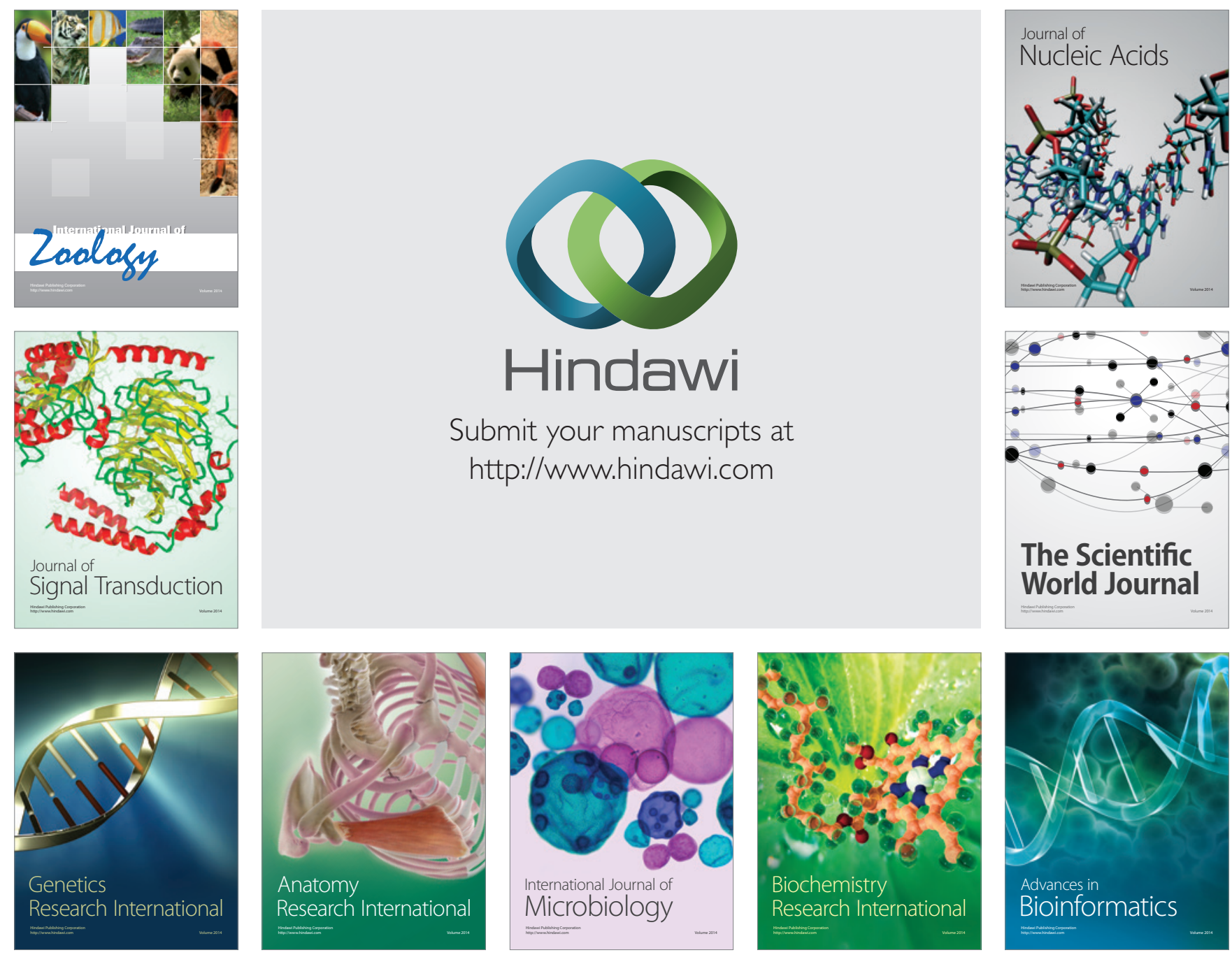

The Scientific World Journal
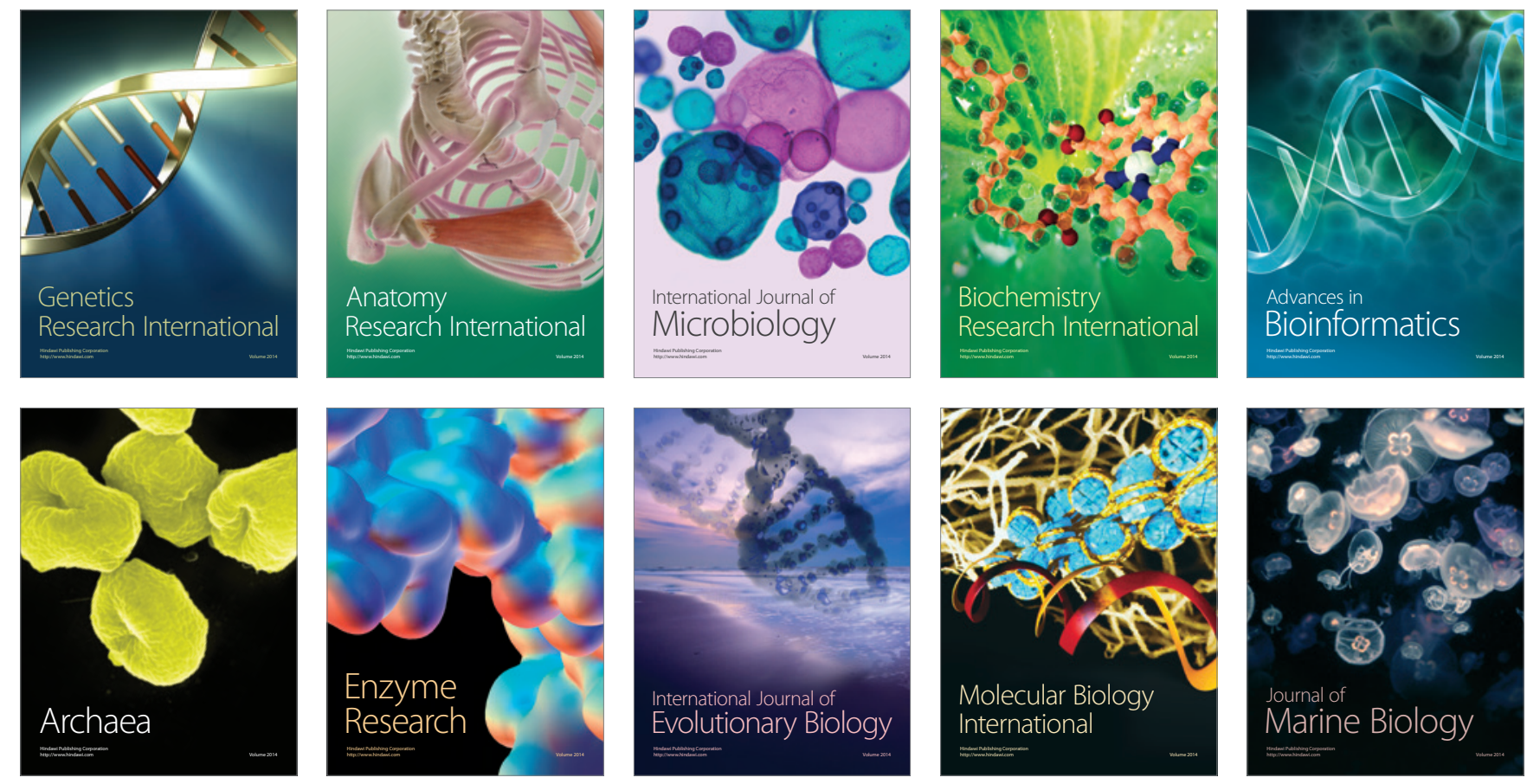